\title{
Electrochemical behavior of iridium and ruthenium in low-temperature melt electrolytes
}

\author{
Anastasiya $\mathrm{SAVCHUK}^{1}$, Nelly TUMANOVA ${ }^{1}$, Victor MALYSHEV $^{1}$ \\ ${ }^{1}$ V.I. Vernadskii Institute of General and Inorganic Chemistry of the Ukrainian National Academy of Sciences, \\ Acad. Palladina Ave 32/34, 03680 Kyiv-142, Ukraine \\ * Corresponding author. Tel.: +380-444243409; e-mail: anastasavchuk@mail.ru
}

Received April 29, 2010; accepted June 29, 2010; available on-line November 5, 2010

The electrochemical behavior of iridium and ruthenium in low-temperature melts based on carbamide and acetamide was studied. It was shown that the electrochemical dissolution of metals in the mentioned melts is accompanied by passivation and results in the formation of $\operatorname{Ir}($ III) and $\operatorname{Ru}$ (III) ammonia complexes, which are discharged to the metal irreversibly in one step. The stationary electrolysis of carbamide and acetamide melts leads to the deposition of metal on the metallic substrates $(\mathrm{Pt}, \mathrm{Cu}, \mathrm{Mo})$ in the form of microcrystalline electroplating.

Iridium / Ruthenium / Kinetics / Electrolysis / Plating

\section{Електрохімічна поведінка іридію та рутенію в низькотемпературних розплавлених електролітах}

\author{
Анастасія САВЧУК $^{1 *}$, Неллі ТУМАНОВА $^{1}$, Віктор МАЛИШЕВ $^{1}$ \\ ${ }^{1}$ Інститут загальної та неорганічної хімї ім. В.І. Вернадського НАН України, \\ просп. Акад. Паладіна 32/34, 03680, ГСП, Київ-142, Україна \\ * Контактна особа. Тел.: +380-444243409; e-mail: anastasavchuk@mail.ru
}

Досліджена електрохімічна поведінка іридію і рутенію в низькотемпературних розплавах на основі карбаміду і ацетаміду. Показано, що електрохімічне розчинення металів у даних розплавах супроводжується пасивацією і приводить до утворення аміачних комплексів $\operatorname{Ir}(\mathrm{III})$ i $\operatorname{Ru}(\mathrm{III})$, які електроактивні і розряджаються в одну стадію необоротно до металу. При стаціонарному електролізі карбамідного і ацетамідного розплавів метали осаджуються на металеві основи (Pt, Сu, Мо) у вигляді дрібнокристалічних гальванічних покриттів.

Іридій / Рутеній / Кінетика / Електроліз / Гальванічні покриття

Вступ

В огляді [1] наводяться результати дослідження електрохімічної поведінки $\mathrm{Pt}, \mathrm{Pd}, \mathrm{Rh}, \mathrm{Ir}, \mathrm{Ru}$ у хлоридних розплавах складу $\mathrm{K}, \mathrm{Na}, \mathrm{Cs} / \mathrm{Cl}$, температура плавлення яких дорівнює $480^{\circ} \mathrm{C}$. Дослідження показали стабільність хлоридних розплавів, що містять $\mathrm{CsCl}$, в інертній атмосфері, на відміну від розплаву $\mathrm{Li}, \mathrm{Na}, \mathrm{K} / \mathrm{Cl}$ [2], в якому приблизно при тих же температурах спостерігається розкладання хлоридів платинових металів, а також на відміну від розплаву $\mathrm{NaCN}-$
$\mathrm{KCN}$, який сам $є$ нестабільним в інтервалі температур $\left(500-600^{\circ} \mathrm{C}\right)$ [3-5]. Потрійна евтектика $\mathrm{KCl}-\mathrm{NaCl}-\mathrm{CsCl}$ (30-24,5-45,5 мол.\%) була використана як розчинник; хлориди платинових металів отримували безпосередньо в розплаві шляхом хлорування відповідного металу або його анодним розчиненням [1]. 3 даного електроліту шляхом електролізу були отримані гальванічні покриття всіх досліджених металів і деяких їх сплавів. Проте, у всіх випадках осади мали дендритоподібну структуру. Для нарощування певної товщини покриття процес електролізу 
зупинявся, отримані покриття полірували або електрохімічним, або механічним способом, а потім знову проводили процес осадження металу. У роботах [6,7] було висловлено припущення, що дендритоутворення під час осадження гальванічних покриттів благородних металів обумовлене тим, що процес осадження металів ведуть при температурах, що перевищують температуру рекристалізації металу $\left(\sim 300^{\circ} \mathrm{C}\right)$. Справді, при використанні як розчинників низькотемпературних розплавів, зокрема карбаміду i ацетаміду [8], базуючись на результатах дослідження електрохімічних властивостей $\mathrm{Pt}, \mathrm{Pd}, \mathrm{Rh}$ були розроблені способи одержання дрібнокристалічних гальванічних осадів макро- і наноструктури.

Метою даної роботи є визначення можливості використання низькотемпературних розплавів на основі карбаміду i ацетаміду для дослідження електрохімічних властивостей Ir i Ru i отримання дрібнокристалічних гальванічних осадів.

\section{Методика експерименту}

Вивчення електрохімічної поведінки іридію i рутенію в карбамід-хлоридному та ацетамідхлоридному розплавах проводили методом циклічної вольтамперометрії, за допомогою потенціостату ПІ 50-1.1 із програматором ПР-8 в інтервалі швидкостей накладання напруги від $1 \cdot 10^{-2}$ до $1 \mathrm{~B} / \mathrm{c}$. Залежність струму від потенціалу реєстрували за допомогою двокоординатного самописця Н307/2. Дослідження проводили в кварцовій електрохімічній комірці за трьохелектродною схемою. Конструкція комірки передбачала можливість проведення експериментальних досліджень як на повітрі, так і в атмосфері аргону. Як робочий електрод використовували платину або досліджуваний метал 3 робочою поверхнею $1-2 \cdot 10^{-2} \mathrm{~cm}^{2}$, допоміжним електродом була Рt-пластина $\left(3,12 \cdot 10^{-2} \mathrm{~cm}^{-2}\right)$ і електродом порівняння напівелемент $\mathrm{Ag} / \mathrm{Ag}^{+}$.

Іони іридію і рутенію вводили в розплав або анодним розчиненням, або хімічним розчиненням солей $\mathrm{IrCl}_{3}$ i $\mathrm{RuCl}_{3}$. Заздалегідь компоненти розчинників - карбамід, ацетамід $\mathrm{i} \mathrm{NH}_{4} \mathrm{Cl}$, а також солі $\mathrm{IrCl}_{3}$ i $\mathrm{RuCl}_{3}$ - висушували у вакуумі при $70-80^{\circ} \mathrm{C}$.

Склад і структуру комплексних сполук іридію і рутенію, що утворилися або в процесі анодного розчинення металу в широкому діапазоні густин струму, або при введенні солей ззовні, визначали методом електронної спектроскопії поглинання (ЕСП) на приладі Specord UV-VIS при електролізі. Швидкоохолоджені розплави досліджували методом ІЧ-спектроскопії на пристрої Specord-M 80. Для експериментальних досліджень використовували евтектичні розплави карбамід-
$\mathrm{NH}_{4} \mathrm{Cl}$ (16,8 мол.\%) і ацетамід- $\mathrm{NH}_{4} \mathrm{Cl}$ (22,3 мол.\%). Морфологію i структуру отриманих осадів досліджували за допомогою растрового електронного мікроскопу РЕМ-101. Склад отриманих гальванічних покриттів визначали рентгенофазовим методом на приладі ДРОН-3. Електрохімічні дослідження, зйомка електронних спектрів та технічний електроліз проводили в розплаві карбамід- $\mathrm{NH}_{4} \mathrm{Cl}$ при температурі $120^{\circ} \mathrm{C}$ i в ацетамід- $\mathrm{NH}_{4} \mathrm{Cl}$ при $80^{\circ} \mathrm{C}$.

\section{Результати та обговорення}

Карбамід-хлоридний розплав. Іридій електрохімічно розчиняється в розплаві карбамід$\mathrm{NH}_{4} \mathrm{Cl}$, але швидкість розчинення незначна, вона дорівнює $2,9 \cdot 10^{-5}$ г/хв. Під час перших зйомок циклограм пасивація іридієвого аноду слабко проявляється, але вже після 3-4 циклів на анодній гілці циклограми спостерігається затримка струму (Рис. 1). Подібний механізм розчинення іридію спостерігався також у розплаві $\mathrm{K}, \mathrm{Na}, \mathrm{Cs} / \mathrm{Cl}$ [1]. На думку авторів, пасивація поверхні іридію обумовлена утворенням сольової плівки, через яку відбувається розчинення металу.

За допомогою гравіметричного i спектроскопічних методів було встановлено, що іридій переходить у розплав карбамід- $\mathrm{NH}_{4} \mathrm{Cl}$ у вигляді іонів $\operatorname{Ir}(\mathrm{III})$. На електронних спектрах після анодного розчинення іридієвого електроду були зафіксовані смуги перенесення заряду, які характеризуються максимумами при $34000 \mathrm{~cm}^{-1} \mathrm{i}$ $32000 \mathrm{~cm}^{-1}$, що свідчить про утворення аміачного комплексу [9], в якому іридій знаходиться в тривалентному стані (Рис. 2).

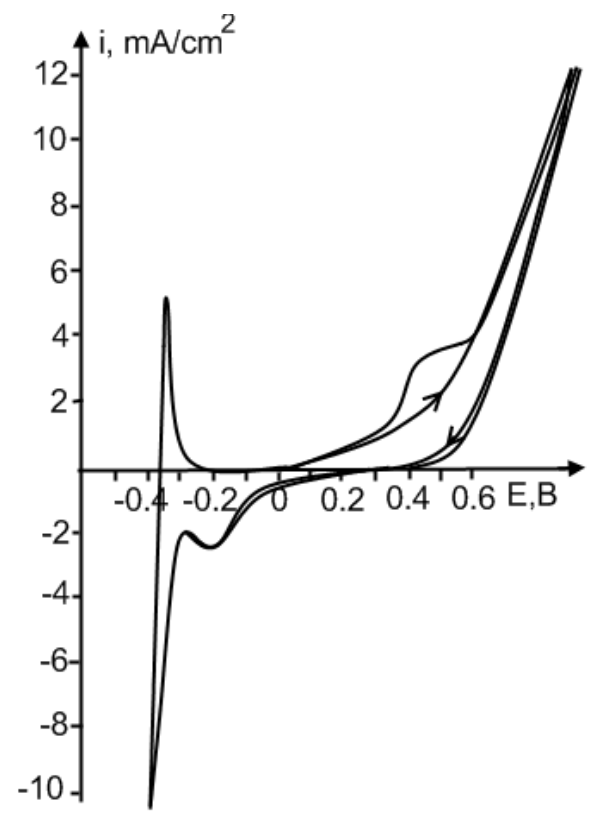

Рис. 1 Циклічна вольтамперограма іридієвого аноду в розплаві карбамід$\mathrm{NH}_{4} \mathrm{Cl} . \mathrm{V}_{\text {пол }}=0,1 \mathrm{~B} / \mathrm{c}, \mathrm{t}_{\text {роб }}^{\circ}=100^{\circ} \mathrm{C}$. 


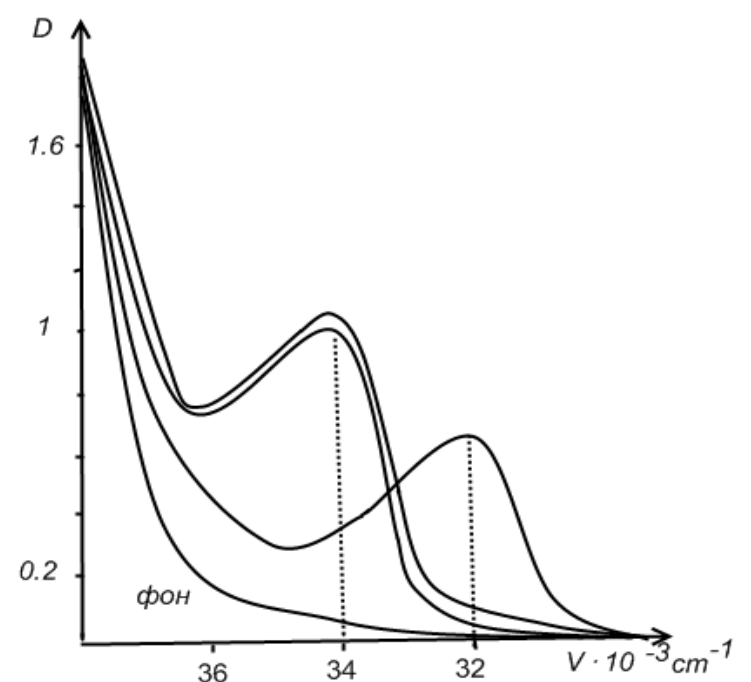

Рис. 2 ЕСП, які були зняті під час анодного розчинення іридієвого аноду.

На ІЧ-спектрах швидкоохолодженого розплаву були зафіксовані частоти коливань, що відображають зв'язок $\mathrm{Ir}-\mathrm{NH}_{3}$ при: $3200 \mathrm{~cm}^{-1}-$ $v_{\text {as }}\left(\mathrm{NH}_{3}\right) ; 1620 \mathrm{~cm}^{-1}-\sigma_{\text {as }}(\mathrm{H}-\mathrm{N}-\mathrm{H}) ; 1350 \mathrm{~cm}^{-1}-$ $\sigma_{\mathrm{s}}(\mathrm{H}-\mathrm{N}-\mathrm{H}) ; 760 \mathrm{~cm}^{-1}$ і $480 \mathrm{~cm}^{-1}-v(\operatorname{Ir}-\mathrm{N})$. Окрім цих максимумів на спектрі присутня також низькочастотна смуга при $290 \mathrm{~cm}^{-1}$, яка характеризує наявність зв'язку з хлором: v( $\mathrm{Ir}-\mathrm{Cl})$ (Рис. 3).

Таким чином, порівняння експериментальних даних з літературними $[9,10]$ дозволяє встановити утворення комплексу $\left[\operatorname{Ir}\left(\mathrm{NH}_{3}\right)_{4} \mathrm{Cl}_{2}\right]^{+}$при електрохімічному розчиненні іридію в карбамідхлоридному розплаві. Даний комплекс $\epsilon$ електроактивним, на катодній гілці циклограми фіксується процес відновлення іонів іридію при потенціалі -0,2 В. Розрахунок основних кінетичних параметрів процесу відновлення іонів іридію проводили згідно з основними критеріями, які наведені в літературі [11]. Дифузійність процесу розряду іонів підтверджена прямолінійністю графіка в координатах $i_{p} / V^{1 / 2} f\left(V^{1 / 2}\right)$ і його паралельністю до осі абсцис. Оборотність катодного процесу визначають із залежності струму піку від швидкості розгортки потенціалу. Одержані нами дані відображають залежність $i_{p}$ від $V^{1 / 2}$, що вказує на необоротність процесу. Цей висновок підтверджується двома іншими критеріями оборотності: різниця потенціалу напівпіку та піку та потенціалів катодного та анодного піків, не дорівнюють теоретичному значенню для оборотного процесу $(2,2 R T / n F)$, що додатково вказують на необоротність процесу розряду комплексних іонів іридію. Електрохімічний коефіцієнт $\alpha n_{\alpha}$ був розрахований 3 основного рівняння для необоротного процесу (1); він дорівнює 1,04 .

$$
E_{p}-E_{p / 2}=-1,857 R T / \alpha n_{\alpha} F
$$

де $E_{p}$ и $E_{p / 2}-$ потенціал струму піку і напівпіку. 3 розрахунків поляризаційних кривих за методикою відповідно рівнянню Рендлса-Шевчика [11] для необоротних, нестаціонарних електродних процесів був розрахований коефіцієнт дифузії іридію, значення якого дорівнює $2,4 \cdot 10^{-6} \mathrm{~cm}^{2} / \mathrm{c}$.

Стаціонарний електроліз при потенціалі катодного піку $\left(i=20 \mathrm{~A} /\right.$ дм $\left.^{2}\right)$ приводить до осадження на поверхні інертної основи (Pt, $\mathrm{Cu}$, Мо) гальванічного покриття. Рентгенофазовий аналіз катодного осаду, отриманого після тривалого електролізу (2 години), підтвердив, що покриття $\epsilon$ чистим іридієм (Рис. 4). Товщина покриття дорівнює 5,4 мкм, проте шляхом зміни часу електролізу (3 години), густини струму (до $i=30 \mathrm{~A} /$ дм $^{2}$ ), а також використанням органічних поверхнево-активних речовин (ПАР) можна не лише збільшити товщину покриття до 6 мкм, але і отримати напівблискуче покриття. За допомогою растрового мікроскопа РЕМ-101 були зроблені мікрофотографії покриттів (Рис. 5).

Покриття рівномірне, добре зчеплене 3 основою, світло-сіре, дрібнокристалічне, глобулярного характеру, напівблискуче. Розмір глобул знаходиться в межах 400-500 нм.

Через низьку розчинність $\mathrm{IrCl}_{3}$ у розплаві його концентрація не перевищувала $0,2 \cdot 10^{-5}$ моль $/ \mathrm{cm}^{3}$, тому введення $\mathrm{IrCl}_{3}$ істотно не впливає ні на електрохімічні характеристики металу, ні на структуру комплексних сполук, що утворилися, ні на якість отриманого осаду. На відміну від $\mathrm{IrCl}_{3}$, хороша розчинність $\mathrm{RuCl}_{3}$ у розплаві дозволила забезпечити необхідну концентрацію іонів металу шляхом розчинення солі. В результаті спектроскопічних досліджень було показано утворення аміачних комплексів Ru(III), але через велику спорідненість рутенію до кисню, навіть в умовах проведення експерименту в атмосфері аргону, на спектрограмі присутній також сигнал, що відображає наявність зв'язку металу з киснем. Висота катодного піку відновлення Ru(III) прямо пропорційна концентрації введеної солі $\mathrm{RuCl}_{3}$ (2; 3,$5 ; \quad 5 \cdot 10^{-3}$ моль $\left./ \mathrm{cm}^{3}\right), \quad$ потенціал відновлення становить $-0,5$ В.

Розрахунок кривих для визначення кінетичних параметрів процесу показує необоротний характер розряду іонів рутенію. Електрохімічний коефіцієнт $\alpha n_{\alpha}=0,25$. Розрахований коефіцієнт дифузії іонів рутенію [11], який дорівнює 2,9.10-6 $\mathrm{cm}^{2} / \mathrm{c}$, знаходиться в тому ж інтервалі величин, що і для Rh [8] i Ir. Стаціонарний електроліз при потенціалі катодного піку приводить до осадження на поверхні основи (Pt, $\mathrm{Cu}, \mathrm{Mo})$ гальванічного покриття товщиною до 12 мкм, рівномірного, добре зчепленого з основою, з розміром частинок 200-300 нм. Рентгенофазовий аналіз катодного осаду показав, що покриття є чистим рутенієм.

Для вивчення механізму анодного процесу осаджували рутенієве покриття на поверхню платинового електрода. Процес проводили 


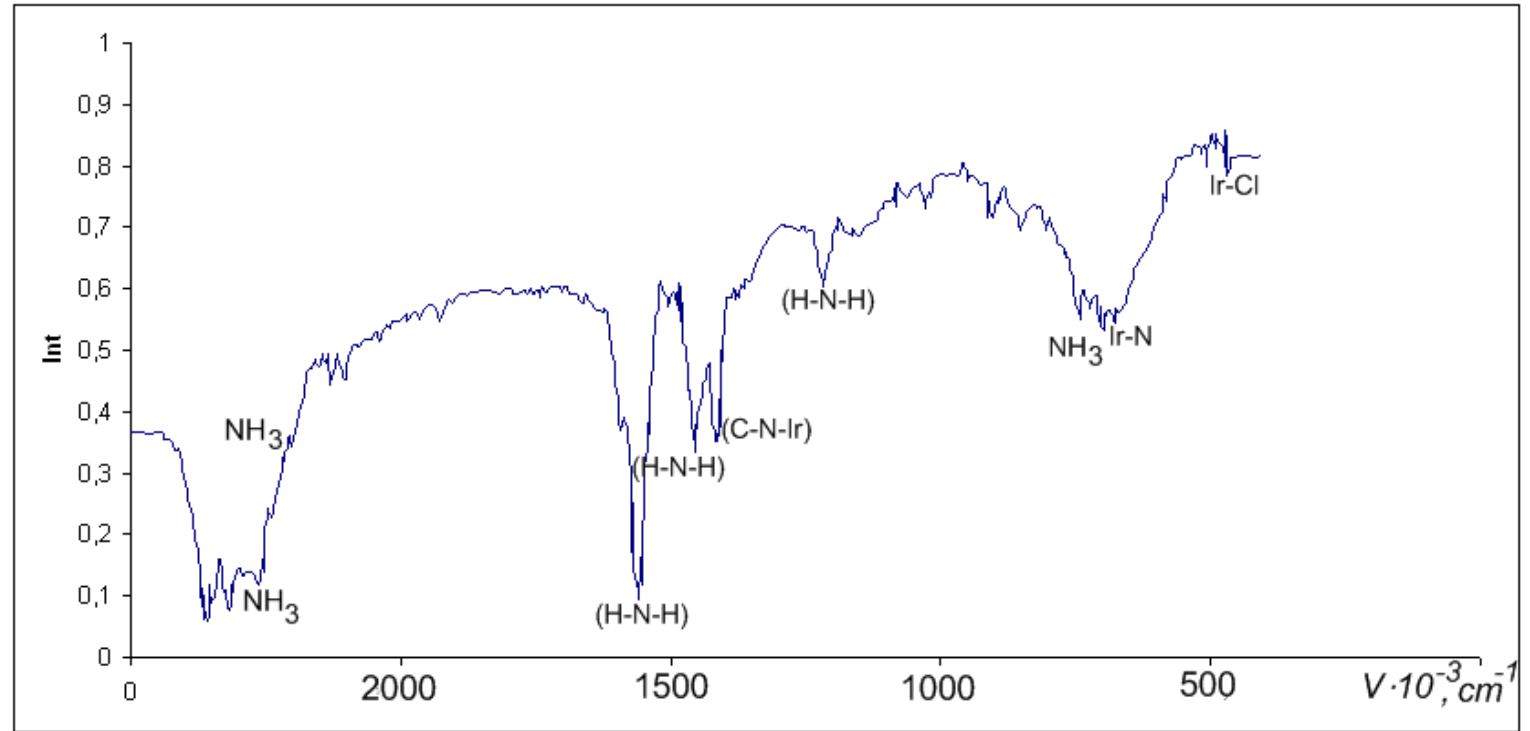

Рис. 3 ІЧ-спектри швидкозагартованого розплаву карбамід- $\mathrm{NH}_{4} \mathrm{Cl}$ після електролізу.

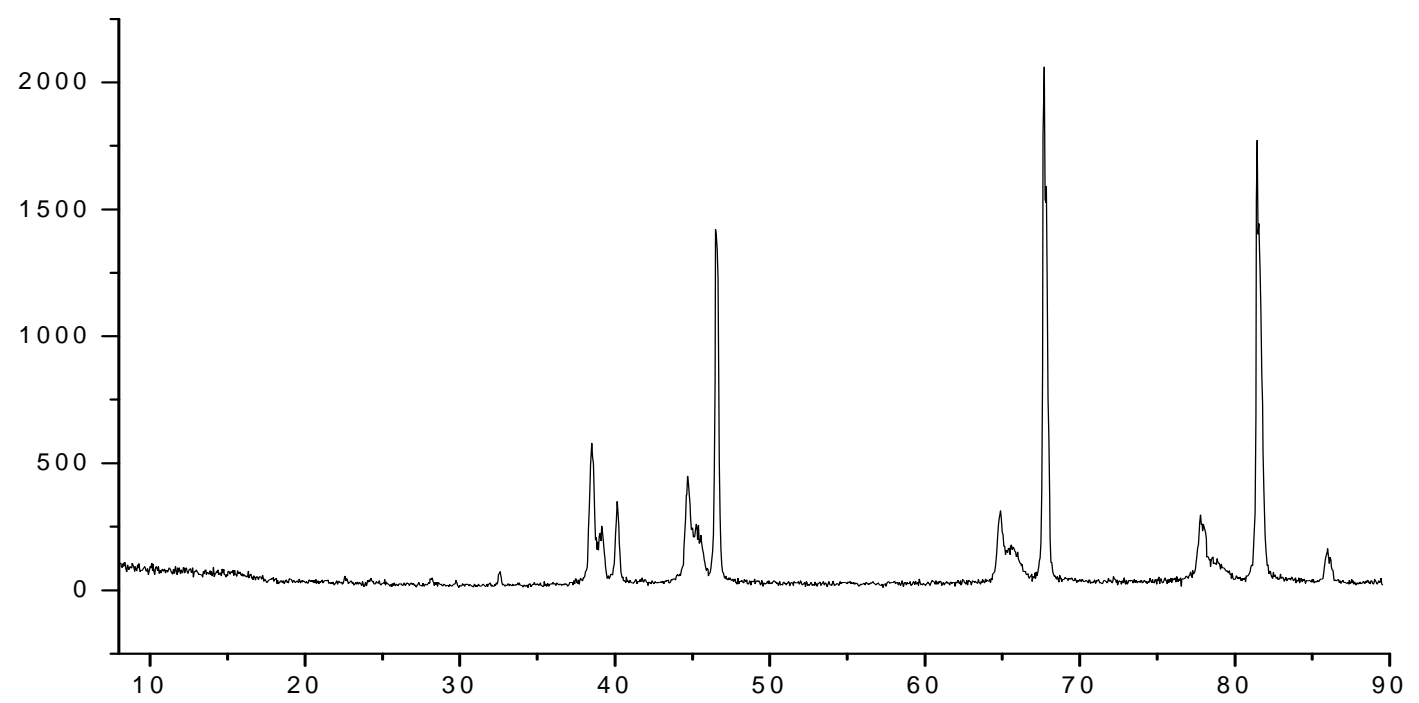

Рис. 4 Рентгенограма іридієвого покриття з розплаву карбамід- $\mathrm{NH}_{4} \mathrm{Cl}$.
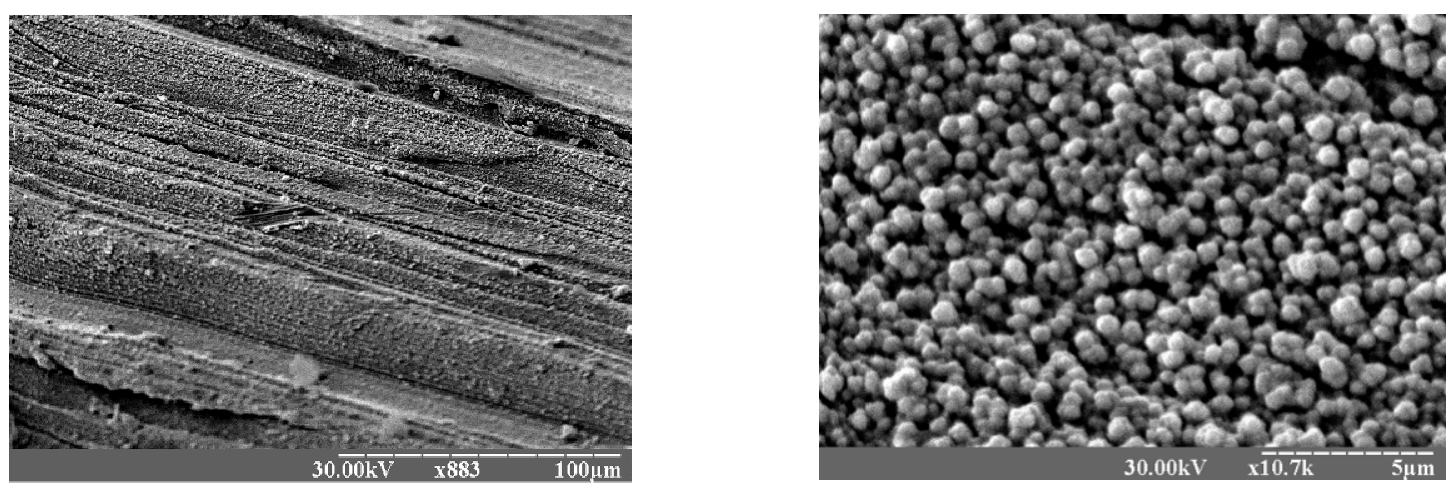

Рис. 5 Мікрофотографія іридієвого покриття з розплаву карбамід- $\mathrm{NH}_{4} \mathrm{Cl}, \mathrm{t}^{\circ}$ роб $=100^{\circ} \mathrm{C}$. 
протягом 3 годин при густині струму $25 \mathrm{~A} /$ дм $^{2}$ та швидкості осадження $1,5 \cdot 10^{-4}$ г/хв. На електроді 3 нанесеним рутенієвим покриттям була знята повна циклограма (Рис. 6). В анодній області потенціалів відображено електрохімічне розчинення металу, уповільнене пасивацією. Катодний процес спостерігався при таких самих значеннях потенціалу, що і при зйомці кривої в умовах, коли іони рутенію вводили в розплав ззовні, у вигляді $\mathrm{RuCl}_{3}$.

Отримані експериментальні дані показують, що низькотемпературний карбамід-хлоридний розплав може бути використаний як електроліт для дослідження електрохімічних властивостей іридію i рутенію, a також для одержання дрібнокристалічних гальванічних покриттів на різних металевих основах.

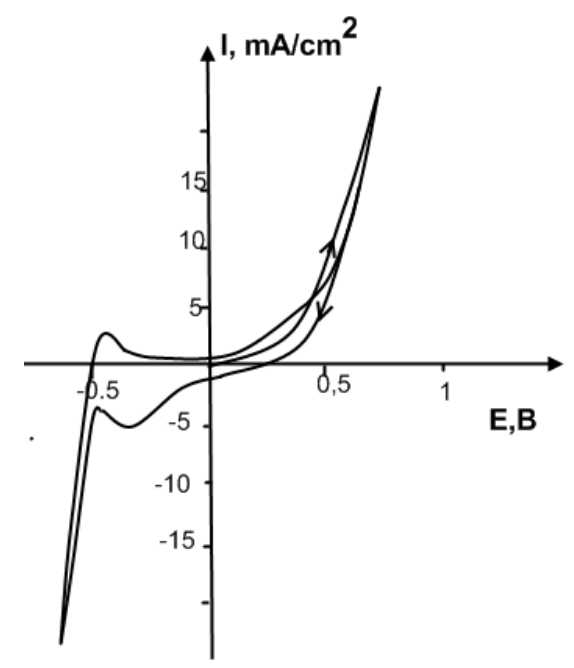

Рис. 6 Циклічна вольтамперограма рутенієвого аноду в розплаві карбамід$\mathrm{NH}_{4} \mathrm{Cl}, \mathrm{V}_{\text {пол }}=0,1 \mathrm{~B} / \mathrm{c}, \mathrm{t}_{\text {роб }}^{\circ}=100^{\circ} \mathrm{C}$.

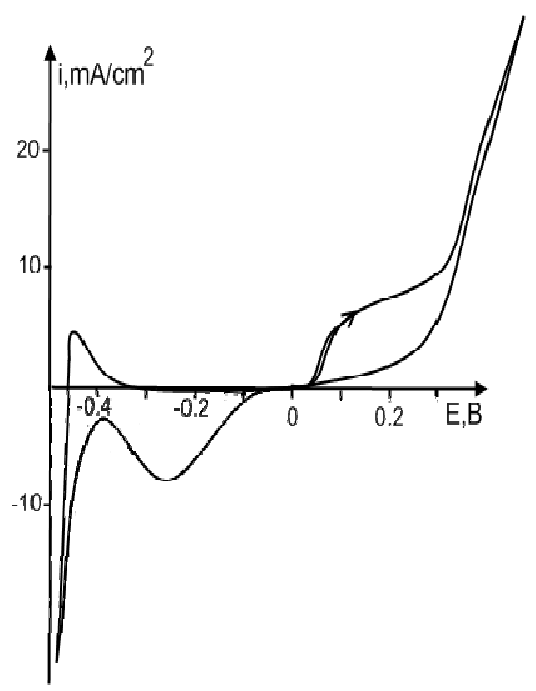

Рис. 7 Циклічна вольтамперограма іридієвого аноду в розплаві ацетамід$\mathrm{NH}_{4} \mathrm{Cl}, \mathrm{V}_{\text {пол }}=0,1 \mathrm{~B} / \mathrm{c}, \mathrm{t}_{\text {роб }}^{\circ}=80^{\circ} \mathrm{C}$.
Ацетамід-хлоридний розплав. Металічний іридій таким же чином як i в карбамід-хлоридному розплаві, електрохімічно розчиняється в розплаві на основі ацетаміду, але 3 меншою швидкістю $\left(1,1 \cdot 10^{-5} \Gamma / \mathrm{xв}\right)$, ніж в карбамідному розплаві $\left(2,9 \cdot 10^{-5}\right.$ г/хв). Затримка струму на анодній гілці циклограми вказує на пасивацію електроду (Рис. 7).

Згідно 3 даними електронної спектроскопії іридій переходить у розплав у вигляді іонів $\operatorname{Ir}(\mathrm{III})$; на спектрі зафіксовані смуги перенесення заряду, які характеризуються максимумами при $33500 \mathrm{~cm}^{-1}$ i $31700 \mathrm{~cm}^{-1}$, що свідчить про утворення аміачного комплексу типу $\left[\operatorname{Ir}\left(\mathrm{NH}_{3}\right)_{4} \mathrm{Cl}_{2}\right]^{+}$. Електрохімічне відновлення комплексу спостерігається у вигляді максимуму на катодній гілці циклограми при потенціалі -0,35 В. Визначення кінетики катодного процесу проводилося згідно з усіма основними критеріями [11], що дало можливість встановити необоротність електродного процесу, розрахувати електрохімічний коефіцієнт $\alpha n_{\alpha}=0,7$ і коефіцієнт дифузії - $1,2 \cdot 10^{-6} \mathrm{~cm}^{2} / \mathrm{c}$.

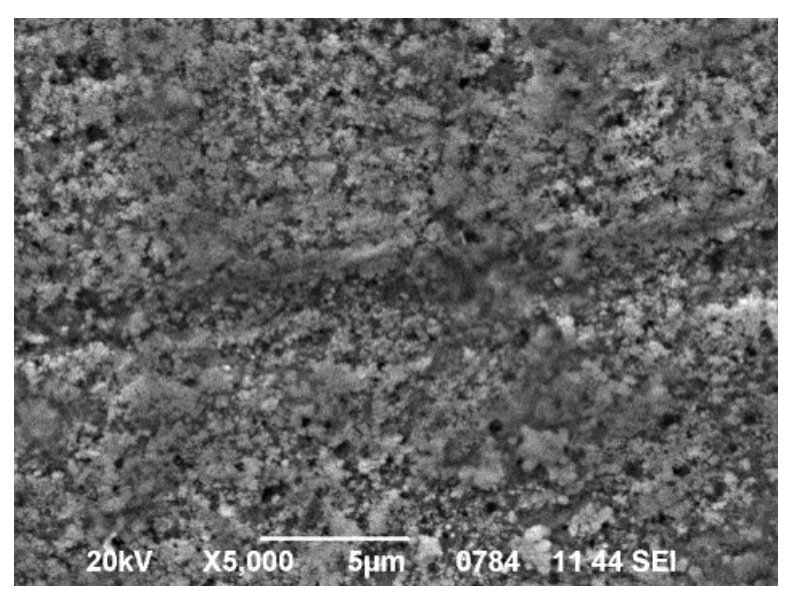

Рис. 8 Мікрофотографія іридієвого покриття з розплаву ацетамід- $\mathrm{NH}_{4} \mathrm{Cl}$.

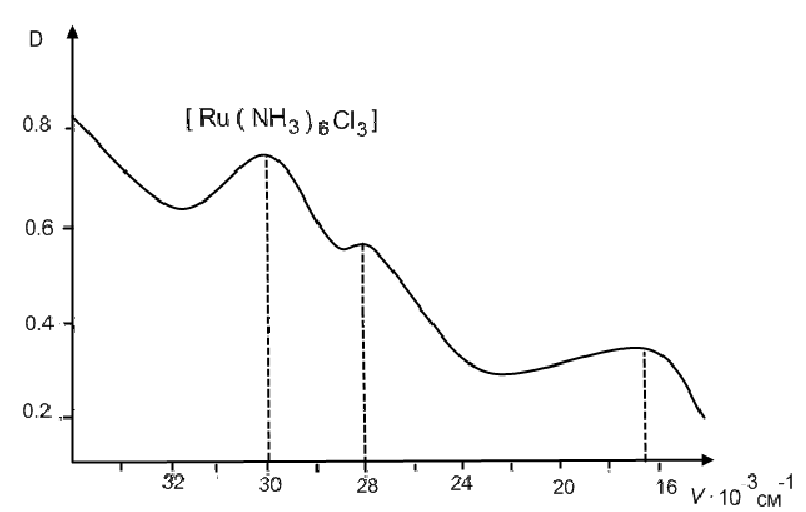

Рис. 9 ЕСП розплаву $\mathrm{CH}_{3} \mathrm{CONH}_{2}-\mathrm{NH}_{4} \mathrm{Cl}-$ $\mathrm{RuCl}_{3}$. 


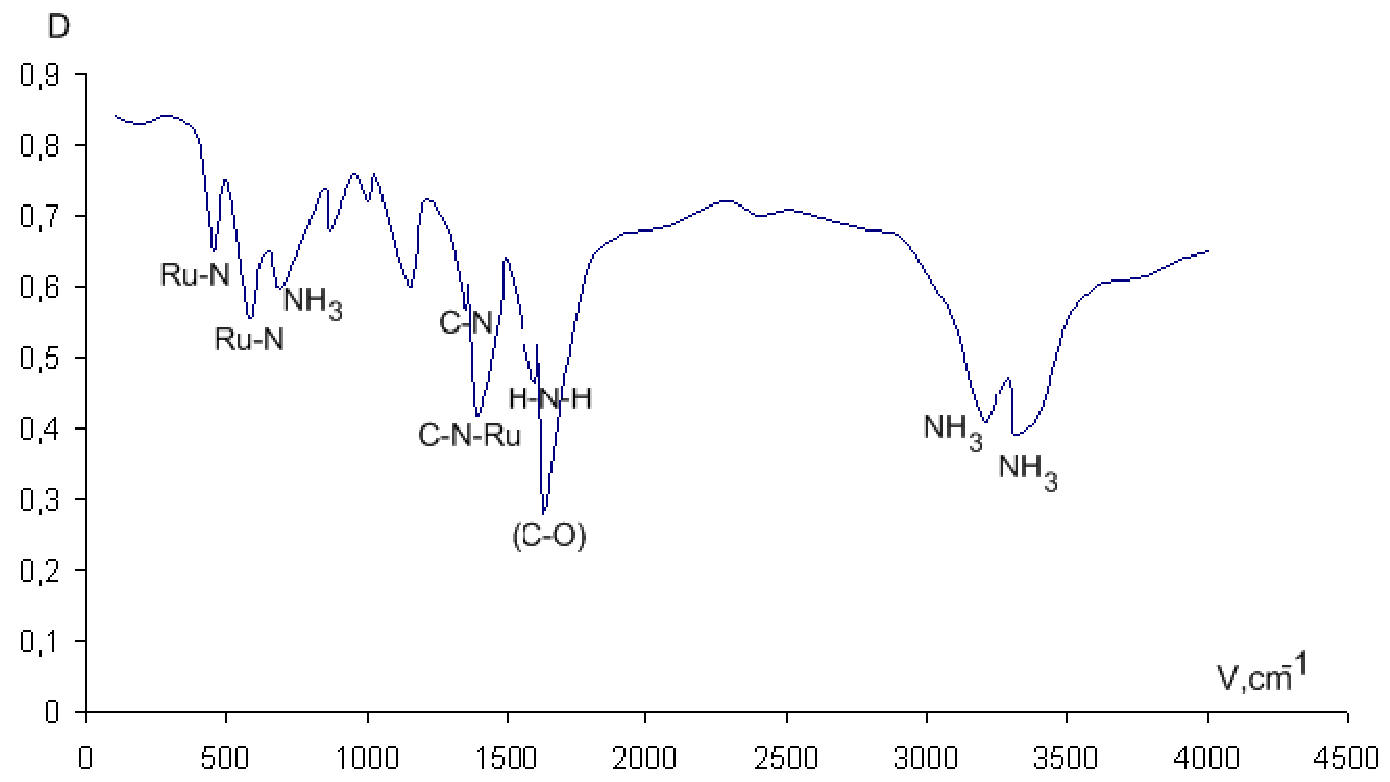

Рис. 10 ІЧ-спектри шводкозагартованого розплаву ацетамід- $\mathrm{NH}_{4} \mathrm{Cl}-\mathrm{RuCl}_{3}$.

Відновлення іонів $\operatorname{Ir}(\mathrm{III})$ відбувається в одну стадію до металу, що підтверджується результатами циклічної вольтамперометрії та рентгенофазного аналізу. При тривалому електролізі можна отримати гальванічне покриття товщиною 5,7 мкм. Покриття дрібнокристалічне, добре зчеплене 3 основою. При додаванні ПАР покриття світлішає та з'являється напівблиск (Рис. 8).

Хлорид рутенію вводили в розплав ацетамід$\mathrm{NH}_{4} \mathrm{Cl}$ у кількостях $1 ; 3 ; 5 \cdot 10^{-5}$ моль $/ \mathrm{cm}^{3}$. Згідно 3 даними електронної спектроскопії (Рис. 9) та ІЧспектроскопії (Рис. 10) в ацетамід-хлоридному розплаві утворюється комплексна сполука $\left[\mathrm{Ru}\left(\mathrm{NH}_{3}\right)_{6} \mathrm{Cl}_{3}\right]$.

Даний комплекс $є$ електроактивним, процес відновлення $\mathrm{Ru}(\mathrm{III})$ спостерігається в катодній частині циклограми при потенціалі $-0,5 \mathrm{~B}$ (Рис. 11).

Аналіз отриманих даних свідчить про дифузійність (залежність струм - концентрація домішки прямолінійна, виходить 3 початку координат) і необоротність процесу $\left(E_{p / 2}-E_{p} \neq\right.$ $2,2 R T / n F)$ при $\alpha n_{\alpha}=0,85$. Розрахований коефіцієнт дифузії за рівнянням Рендлса-Шевчика дорівнює $2 \cdot 10^{-6} \mathrm{~cm}^{2} / \mathrm{c}$. Відновлення іонів рутенію йде в одну стадію необоротно до металу, що підтверджує рентгенофазовий аналіз осаду, отриманого шляхом електролізу при потенціалі катодного піку. При швидкості осадження $1,7 \cdot 10^{-4}$ г/хв протягом трьох годин було отримано гальванопокриття Ru (на Pt i $\mathrm{Cu})$ товщиною до 13,5 мкм.

Платиновий електрод 3 нанесеним рутенієвим покриттям був використаний як анод, що дозволило вивчити механізм анодного процесу i визначити, що електрохімічне розчинення металу протікає із слабкою пасивацією.

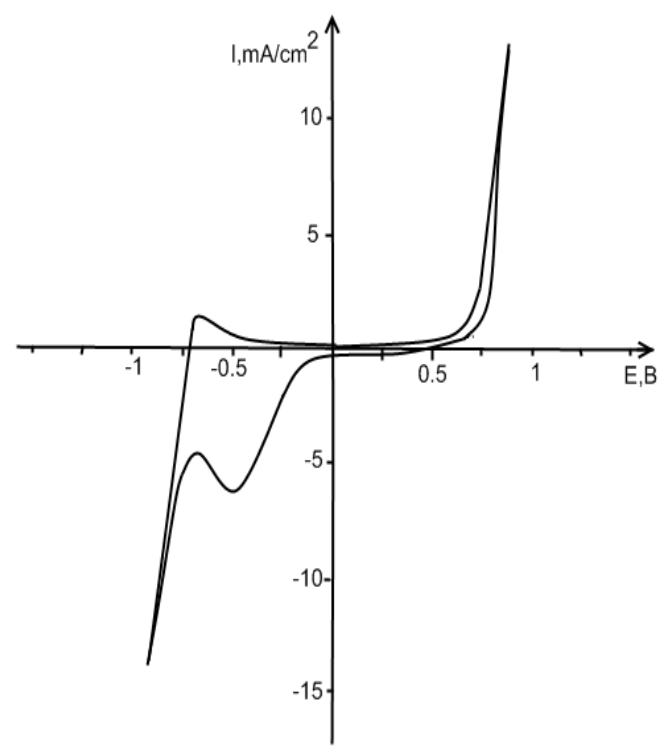

Рис. 11 Циклічна вольтамперограма рутенієвого аноду в розплаві ацетамід$\mathrm{NH}_{4} \mathrm{Cl}, \mathrm{V}_{\text {пол }}=0,1 \mathrm{~B} / \mathrm{c}, \mathrm{t}_{\text {роб }}^{\circ}=80^{\circ} \mathrm{C}$.

\section{Висновок}

Таким чином, ацетамід-хлоридний розплав та карбамід-хлоридний розплави можуть бути використані для вивчення механізму i кінетики електрохімічного процесу розчинення благородних металів, комплексоутворення їх іонів 3 компонентами розплаву і катодного відновлення комплексних іонів Ir i Ru на різних металевих основах. Процес відновлення іонів $\operatorname{Ir}(\mathrm{III}), \mathrm{Ru}(\mathrm{III})$ 
до металу у обох розплавах відбувається необоротно. Коефіцієнти дифузії знаходяться у межах $1-3 \cdot 10^{-6} \mathrm{~cm}^{2} / \mathrm{c}$, притому, що в карбамідхлоридному розплаві вони вищі, ніж в ацетамідному. Швидкість осадження металів невелика, проте при тривалому електролізі (до 3 годин) можна отримати гальванічне покриття товщиною 5-12 мкм. Покриття дрібнокристалічне, 3 розміром частинок приблизно 400-500 нм, 3 хорошою адгезією до основи (Pt, $\mathrm{Cu}, \mathrm{Mo})$, напівблискуче.

\section{Літературні посилання}

[1] N.A. Saltykova, J. Mining Metal. 20(1-2) (2003) 201-209.

[2] R.N. Atkinson, Trans. Faraday Soc. 26(8) (1930) 490-496.

[3] R.N. Rhoda, Plating 49 (1) (1962) 69-71.

[4] G.R. Smith, C.B. Kenahan, R.I. Andrews, D. Sclain, Plating 56 (7) (1969) 805-809.
[5] D. Schlain, F.X. McCawley, G.R. Smith, Platinum Met. Rev. 21 (1977) 38-41.

[6] Физический энизилопедический словарь, Советская энциклопедия, М., 1945, Т. 4, c. 408 .

[7] Н.А. Салтыкова, В.Е. Барабошкин, Высокочист. Вещества 3 (1994) 84-89.

[8] Н.Х. Туманова, С.А. Кочетова, А.В. Савчук, Наук. Вісн. Чернівецьк. Унів., Сер. Хім., 399400 (2008) 52-54.

[9] Э. Ливер, Электронная спектроскопия неорганических соединений, В 2-х частях: Пер. с англ., Мир, М., 1987, Ч. 1, 494 с., Ч. 2, $444 \mathrm{c}$.

[10] К. Накамото, ИК спектры и спектры КР неорганических и координационных соединений, Мир, М., 1991, 536 с.

[11] 3. Галюс, Теоретические основы электрохимического анализа, Мир, М., 1974, $552 \mathrm{c}$. 